\title{
RESTRAINTS UPON THE ALIENATION OF LEGAL INTERESTS: II*
}

\author{
MERRILL I. SCHNEBLY†
}

\section{Restraints Qualified as to the Alienee}

$\mathrm{H}^{\mathrm{REQUENTLY}}$ restraints are qualified as to the alienee, so that they F do not restrain alienation completely for the periods within which they are operative. This kind of qualification may exist along with, or separately from, the time qualification discussed in the preceding subdivision. If a restaint is qualified both as to time and alienee, it is a much less objectionable restraint than if it were not limited in any respect, or limited only as to duration. Even a perpetual restraint might be regarded as not seriously objectionable if so qualified as to allow alienation to the great majority of possible purchasers.

To facilitate discussion, restraints qualified as above mentioned are divided into three classes: first, those restraints which allow alienation only to a small group of persons; second, those restraints which permit alienation to anyone except a small group; and third, those which allow alienation to a substantial portion of society, but deny it with respect to a large social group.

A restraint which allows alienation only to the members of a small group is substantially as objectionable as a complete restraint for the same period of time. When alienation is limited to a small number of persons, transfer of the property is not likely to occur. The members of the group may not desire to buy. A sale, moreover, with so small a field of prospective purchasers, will likely involve so great a sacrifice of value that the owner will refuse to sell. ${ }^{140}$

Restraints of the class now under consideration may be phrased in either the disabling or the forfeiture form. A good illustration of a perpetual disabling restraint is found in the recent Kentucky decision in Courts v. Courts' Guardian. ${ }^{147}$ A testator devised land to his greatnephew, with a provision that it should not be sold "out of the name Courts." The restraint was held unreasonable and therefore void. ${ }^{148}$ In a well known English case, a testator devised land to his son, "with an injunction never to sell it out of the family; but if sold at all, it must be to one of his brothers hereinafter named." This restraint, properly construed, would seem clearly limited to the life of the devisee

*Continued from 44 YaLe L. J. 961.

$\uparrow$ Professor of Law, University of Illinois.

146. Chappell v. Frick Co., $166 \mathrm{Ky} .311,179$ S. W. 203 (1915).

147. $230 \mathrm{Ky} .141,18 \mathrm{~S}$. W. (2d) 957 (1929).

148. Accord: Hacker v. Hacker, 75 Misc. 380, 133 N. Y. Supp. 266 (Sup. Ct. 1912), 153 App. Div. 270, 138 N. Y. Supp. 194 (2d Dep't, 1912). 
himself. It was held void. ${ }^{149}$ The same conclusion has been reached in several other cases involving disabling restraints limited in time, and permitting alienation to a very few persons. ${ }^{150}$

Forfeiture restraints qualified so as to allow alienation to a few persons have, however, been upheld in some decisions. The leading authorities for this view are two English cases. In Doe d. Gill v. Pearson, ${ }^{151}$ decided by the King's Bench in 1805, a devise was made upon the condition that if the devisee should have no issue, she should not have power to dispose of her interest, "except to her sister or sisters, or to their children." Upon conveyance outside of the permitted group, a forfeiture was enforced. ${ }^{152}$ While this decision was repudiated as a precedent by Sir John Romily, M.R., in a later case, ${ }^{153}$ it was followed by Sir George Jessell, $M$. R., in Re Macleay. ${ }^{15}$ Here the devise was upon condition that the devisee should never "sell" the land "out of the family." SEs Serious doubt is cast upon the decision last mentioned in $R e$ Rosher, ${ }^{156}$ which appears to be the latest English precedent bearing directly on the point. ${ }^{157}$ In Canada, where great liberality has been manifested toward qualified restraints, a few decisions have followed the English rule adopted by In Re MIacleay.15s The American authority is decidedly opposed to the validity of restraints of this kind, whether perpetual in duration, ${ }^{159}$ or limited in time. ${ }^{160}$

149. Attwater v. Attwater, 18 Beav. 330 (Rolls Ct. 1853).

150. Crandall v. White, $277 \mathrm{Ill}$. App. 371 (1934); Chsppell v. Frick Co., $165 \mathrm{Ky}$. 311, 179 S. W. 203 (1915); Anderson v. Cary, 36 Ohio St. 506 (18s1); Ar'Cullough's Heirs v. Gilmore, $11 \mathrm{~Pa} .370$ (1849); see Chappell v. Chappell, $119 \mathrm{~S}$. W. 218, 219 (Ky. 1959). But see Smith v. Faught, 45 U. C. Q. B. 484 , 488 (1881).

151. 6 East 173 (K. B. 1805).

152. The restraint in this case was limited to the life of the conveyee.

153. Attwater v. Attwater, 18 Beav. 330 (Rolls Ct. 1853). The restraint in this case was in the disabling form, but no emphasis was put upon that fact; the suit was for construction of the conveyance. Doe d. Gill v. Pearsors was repudiated by the Irieh court in Billing v. Welch, 6 Ir. R. C. L. 88 (1871).

154. L. R. 20 Eq. 186 (1875). See also Miartin v. Miartin, L. R. 19 Ir. 72, 80 (1886). 155. The restraint was limited to the life of the devisee, and was further qualified, in the opinion of the court, to permit a lease or mortgage. See infra, subtitle II, D.

156. 26 Ch. D. S01 (1884).

157. For a detailed discussion of the English cases, see Sweet, Restraints Upon Alicration (1917) 33 L. Q. Rev. 236, 342-348. It is there suggested that the decisions in Doe d. Gill v. Pearson, and in In re Macleay, were induced by a misunderstanding of earlier Engieh cases.

158. Pennyman v. MicGrogan, 18 U. C. C. P. 132 (1S68) (restraint for 20 years, parmitting alienation to sons of the conveyor). In O'Sullivan v. Phelan, 17 Ont. Rep. 730 (1889), the court held valid a restraint for the life of the conveyee, which allowed alienation by deed only to persons of the conveyor's name and family. There was but one possible alienee at the time of the suit. The restraint was construed, however, to parmit a devise outside of the limited group.

159. Brown v. Hobbs, 132 IId. 559, 104 Atl. 283 (1918) (alienation to parsons of the name and blood of the conveyor allowed); see Schermerhorn v. Negus, 1 Denio 448, 450 (N. Y. 1845) (alienation to descendants of conveyor permitted).

160. Rea v. Bell, $147 \mathrm{~Pa}$. 118, 23 Att. 349 (1892) (restraint for life of conveyee, allow- 
A restraint which permits alienation to everyone except a very small number of persons is relatively much less objectionable than restraints of the nature discussed above. In practice such a restraint may not offer any serious impediment to transfer. Restraints of this class are scarcely ever phrased in the disabling form. Where the intent is to restrain alienation to a few particular persons, the restraint is likely to take the forfeiture form; since the conveyor is usually moved by a strong emotional antagonism toward the specified persons, he will probably think of a penalty for violation of the injunction not to sell to them. The pertinent decisions, therefore, involve forfeiture restraints. ${ }^{101}$ While the authorities are few, the weight of judicial opinion is probably against the validity of even this relatively harmless kind of restraint. This state of the authorities is surprising, especially when it is noted that this type of restraint is the one declared to be permissible by Littleton, whose statement on the point has been quoted in the decisions times without number. ${ }^{162}$

The explanation probably lies in the fact that restraints of this class are almost always so phrased that they operate in point of fact as complete restraints. In Morse $v$. Blood, ${ }^{\mathbf{1 6 3}}$ a devise of all the property of the testator was upon the condition that the devisee should not "give or bequeath one cent of said estate to any member of my family, or to any relation of her own." The restraint was held void, the court pointing out emphatically that no purchaser could safely buy any parcel of the property devised, since he would incur the risk of a divestiture if the devisee should subsequently convey to a member of the designated group any part of the residue of the property. ${ }^{104}$ Thus, the restraint

ing alienation to but one named person); Manierre v. Welling, 32 R. I. 104, 78 Atl, 507 (1911) (restraint for life of conveyee, allowing alienation to descendants of conveyor).

The liberal Kentucky rule permits any restraint of the forfeiture type, "reasonably" limited in time. A restraint for twenty years, allowing alienation only to descendants of the conveyor is valid. Francis v. Big Sandy Co., $171 \mathrm{Ky} .209,188 \mathrm{~S} . \mathrm{W} .345$ (1916); Price v. Virginia Iron Co., $171 \mathrm{Ky} .523,188 \mathrm{~S}$. W. 658 (1916). A restraint for the life of the conveyee, similarly qualified, is void. Carpenter v. Allen, $198 \mathrm{Ky} .252,248 \mathrm{~S}$. W. 523 (1923) ; cf. Chappell v. Frick Co., 166 Ky. 311, 179 S. W. 203 (1915).

161. In Barnard's Lessee v. Bailey and Kettlewood, 2 Harr. 56 (Del. 1836), the court, in a dictum, declared void a restraint disabling in form, which prohibited allenation to the kin of either the conveyor or the conveyee.

162. "But if the condition be such, that the feoffee shall not alien to such a one, naming his name, or to any of his heirs, or of the issues of such a one, \&c., or the like, which conditions do not take away all power of alienation from the feofice, \&c., then such condition is good." Littleton's Tenures (Wambaugh, 1903) $\$ 361$. This quotation has frequently been relied upon to support the validity of restraints qualified in a way very different from that mentioned.

163. 68 Minn. 442,71 N. W. 682 (1897).

164. Allusion was also made to the fact that a condition, creating a power of reentry in the heirs of the conveyor, was not an appropriate means of effectuating the purposc of the conveyor, since his own heirs were included in the prohibited group. See also Ludlow v. Bunbury, 35 Beav. 36 (Ch. 1865). 
actually precluded all alienation of the property, except as one entire lot. Somewhat the same situation existed in Jenne v. Jenne, ${ }^{105}$ although the fact was not mentioned in the decision, which held the restraint invalid. There a will disposed of both real and personal property to several different persons, and contained a stipulation that no beneficiary should give any part of the property received thereunder to either of two named persons; it also contained the further provision: ".... and in event that this should occur, then my entire estate, or any part thereof that may yet be obtained, shall be given to the legal heirs of my three (3) half sisters. ..." Read literally, this will provided for a forfeiture of the interests of all the beneficiaries if any one of them should transfer to either of the specified persons. Such a restraint would operate as a practical bar to alienation by any devisee so long as any other one might live and retain any portion of the property received under the will. In Overton v. Lea, ${ }^{168}$ the restraint was open to the same objection as that in Morse v. Blood, supra, but, nevertheless, it was held valid. If it is desired to make a restraint of this type effective, it should certainly be so phrased as to create a forfeiture only of such portion of the property as may be transferred to a member of the prohibited group.

Restraints which prohibit alienation to members of a social group of considerable size are definitely more objectionable than the class of restraints last discussed, though less obnoxious to public policy than those which allow alienation only to a small number of particular persons. Restraints of the kind now to be considered are usually directed against alienation to members of minority racial groups; while they may operate to restrain alienation to a large number of persons, in practical effect they usually allow transfer to the majority of possible purchasers. Diverse and competing social policies enter into the problem of restraints at this point. Segregation of races may be socially desirable, as tending to eliminate racial friction, ${ }^{107}$ and to promote the independent development of the minority group. Statutes and ordinances requiring segregation of races in various situations have been held valid under the fourteenth amendment to the United States Constitution, and under the provisions of state constitutions. ${ }^{108}$ A fortiori, there is no

165. 271 IIl. $526,529,111$ N. E. 540,541 (1916).

166: 108 Tenn. 505, 68 S. W. 250 (1902); see also Blachstone Bank v. Davis, 33 Mass. 42, 43 (1838); Cornelius v. Ivens, 26 N. J. L. 376, 385 (1857). But cf. Willizm v. Jones, 32 Tenn. 620 (1853).

167. Queensborough Land Co. v. Cazeau, 136 La. 724, 67 So. 641 (1915); Koehler v. Rowland, 275 Mo. 573, 205 S. W. 217 (1918). See the remarls of Brown, J., in Plesy v. Ferguson, 163 U. S. 537, 551 (1896); and of Day, J., in Buchanan v. Warley, 245 U. S. 60,80 (1917).

168. A statute requiring segregation of races upon trains is constitutional: Plesy v. Ferguson, supra note 167. Likewise, an order of a school board requiring membars of a race to attend a particular school. Roberts v. City of Boston, 59 Macs. 198 (1849). 
breach of any constitutional guaranty in a rule of law which makes enforceable a restraint upon alienation arising from the agreement of private individuals, even though the restraint is directed against a group of a particular race, or color. ${ }^{169}$ The problem, then, is not one of constitutional law, but of the social expediency of racial segregation at the expense of freedom of alienation. In this conflict of competing social policies, obviously that one will prevail which, in the particular jurisdiction, may be deemed to have the greater value.

Where the restraint has been phrased in the forfeiture form, the decisions have divided almost evenly. The restraint has been held valid, and the forfeiture enforced, in Louisiana ${ }^{170}$ and Missouri; ${ }^{171}$ but in California ${ }^{172}$ and Michigan, ${ }^{173}$ such a restraint is void.

Since restrictions of this type are inserted in a conveyance for the primary benefit of other land in the vicinity, and are designed to preserve a certain character of neighborhood, they are more likely to be phrased as covenants against alienation, or as disabling restraints, than as resstraints of the forfeiture type. Where no forfeiture has been stipulated, the purpose of these restrictions can be effectuated only by treating them as creating covenants which run with the land in equity. A mere dis-

In Buchanan v. Warley, 245 U. S. 60, 81 (1917), the United States Supreme Court held unconstitutional an ordinance of the city of Louisville, Kentucky, which made it a criminal offense for any negro to occupy a house in any block where the majority of the resldents were white persons, and vice versa. The decision, however, was not based upon any discrimination against the negro. "The right which the ordinance annulled was the civil right of a white man to dispose of his property if he saw fit to do so to a person of color and of a colored person to make such disposition to a white person." See Bruce, Racial Zoning by Private Contract, etc. (1927) 21 ILL. L. REv. 704. This decision 19 difficult to reconcile with other decisions of the same court upholding the validity of zoning ordinances which do not involve race segregation, but which must frequently operate just as prejudicially to the right of a property owner to transfer his property. Sce Villago of Euclid v. Ambler Realty Co., 272 U. S. 365 (1926); Zahn v. Board of Public Works of Los Angeles, 274 U. S. 325 (1927).

169. This is doubtless assumed in all the decisions sustaining restraints against alienation to a particular social group. In the cases where the problem of constitutionality has been expressly discussed, such restraints have been held constitutional with practical unanimity. Corrigan v. Buckley, 271 U. S. 323 (1926); Torrey v. Wolfes, 6 F. (2d) 702 (App. D. C. 1925); Los Angeles Investment Co. v. Gary, 181 Cal. 680, 186 Pac. 596 (1919); Queensborough Land Co. v. Cazeau, 136 La. 724, 67 So. 641 (1915); Clark v. Vaughan, 131 Kan. 438, 292 Pac. 783 (1930); Parmalee v. Morris, 218 Mich. 625, 188 N. W. 330 (1922); Porter v. Barrett, 233 Mich. 373, 206 N. W. 532 (1925); White v. White, 108 W. Va. 128, 150 S. E. 531 (1929). The only actual dissent found is Gandolfo v. Hartman, 49 Fed. 181 (S. D. Cal. 1892), which was decided in part upon another ground. This decision cannot be viewed as important since Corrigan v. Buckley, suprec. See also Miller v. Jersey Coast Resorts Corporation, 98 N. J. Eq. 289, 297, 130 Atl. 824, 828 (1925).

170. Queensborough Land Co. v. Cazeau, 136 La. 724, 67 So. 641 (1915) (restraint for 25 years against alienation to negroes).

171. Koehler v. Rowland, 275 Mo. 573, 205 S. W. 217 (1918) (restraint for twenty-five years against alienation to negroes). 
abling restraint benefits no one but the conveyee who is subject thereto; it benefits him in so far as it prevents his dissipation of the property, and prevents a creditor from seizing it to satisfy a debt. The benefit of restrictions against alienation to a particular group is intended to accrue to the conveyor of the land, and to every other person who may own any portion of the land protected by the restriction. The only effective remedy is an injunction against alienation to a member of the excluded class, or against occupancy by such a member, or equivalent equitable relief. ${ }^{174}$ It is natural, therefore, that such a restriction should be construed to create a covenant even though its language may be more appropriately that of a disabling restraint, ${ }^{175}$ which would merely deprive the conveyee of the power to transfer, and would not afiord a remedy to the owner of the land intended to benefit. Where there is doubt whether a forfeiture has been stipulated, it would be reasonable to construe the restriction to create a covenant, since a covenant would more completely accomplish the desired purpose than a forfeiture, which can be taken advantage of only by the conveyor or the donee of an express gift over.

The treatment of this kind of restriction as a covenant, and its specific enforcement in equity, gives to it, within its scope, the substantial effect of a disabling restraint. The conveyee has a legal power to transfer to a member of the excluded group, and such a transfer will not cause a forfeiture of his interest. The exercise of this legal power, however, can be prevented in equity by an injunction against such transfer, or can be nullified by a decree setting aside the deed of transfer. The re-

172. Los Angeles Investment Co. v. Gary, 181 Cal. 680, 186 Pac. 596 (1919) (rectrint for 12 years against alienation to non-Caucasians); Title Guarantee \& Trust Co. v. Garrott, 42 Cal. App. 152, 183 Pac. 470 (1919) (restraint for 14 years against alienation to parsors of African, Chinese or Japanese descent).

173. Porter v. Barrett, 233 MTich. 373, 206 N. W. 532 (1925) (restraint against alienation to negroes). This case is more significant by reason of the fact that the restraint was contained in a contract to convey land. It might, therefore, have been vieved as a restraint merely upon the assignment of rights under the contract, and walid as such. See Goddard, Non-Assignment Provisions in Land Conlracts (1932) 31 MIrer. L. REv. 1; Grismore, Effect of a Restriction on Assignment in a Contract (1933) 31 Mircr. L. REv. 299.

174. The remedy of money damages obtainable in an action at how on the covenant is obviously inadequate. The covenant, moreover, does not run at how with the land in all instances.

175. Parmalee v. Morris, 218 Mich. 625,188 N. W. 330 (1922); Schulte v. Starks, 238 Mich. 102, 213 N. W. 102 (1927) ; People's Pleasure Park Co. v. Rohleder, 109 Va. 439, 61 S. E. 794 (190S), rehearing denied, 63 S. E. 981 (190\$). The two cares first cited involved restrictions upon occupancy as distinguished from restraints upon alienation, but they serve equally well to illustrate the principle of construction suggested. But cf. White v. White, 108 W. Va. 128, 150 S. E. 531 (1929), which seems to indicate an inclinstion to construe those restrictions as forfeiture restraints. As to the effect of an agreament to execute a covenant, see Mueninghaus v. James, 324 MIo. 767, 24 S. W. (2d) 1017 (1930). 
striction as thus enforced, does not prevent an execution sale of the property to a purchaser outside of the excluded class.

In the United States Supreme Court, ${ }^{176}$ and in the courts of the District of Columbia, ${ }^{177}$ several decisions have enforced restrictions against transfer to negroes, either by injunction against transfer, ${ }^{178}$ or by decrees setting aside transfers. ${ }^{170}$ The same view appears to be accepted in Kansas and Colorado. ${ }^{180}$ In West Virginia, however, injunctive relief has been denied on the ground that such a covenant is a void restraint upon alienation, depriving the landowner in large degree of the power to alienate by excluding a considerable number of possible purchasers. ${ }^{181}$

It appears, then, that the weight of authority is at least slightly in favor of these restrictions. Even in those jurisdictions which deny validity, substantial accomplishment of the purpose of the restriction is quite simple. While a restraint upon alienation to any person not of the Caucasian race is void in California, a restraint upon occupancy of the land by such a person is valid. ${ }^{182}$ Now it is apparent that, however a restraint

176. Corrigan v. Buckley, 271 U. S. 323 (1926); see also decision in the Court of Appeals of D. C., 299 Fed. 899 (App. D. C. 1924) (restraint for 21 years against alienation to negroes).

177. Torrey v. Wolfes, 6 F. (2d) 702 (App. D. C. 1925) (perpetual restraint against alienation to negroes); Russell v. Wallace, 30 F. 2d 981 (App. D. C. 1929) (restraint against alienation to non-Caucasians); Cornish v. O'Donoghue, 30 F. (2d) 983 (App. D. C. 1929) (as in Torrey v. Wolfes, supra).

178. Corrigan v. Buckley, 299 Fed. 899 (App. D. C. 1924); Torrey v. Wolfes, 6 F. (2d) 702 (App. D. C. 1925).

179. Russell v. Wallace; Cornish v. O'Donoghue, both supra note 177; cf. Torrey v. Wolfes, 6 F. (2d) 702 (App. D. C. 1925).

180. In Clark v. Vaughn, 131 Kan. 438, 292 Pac. 783 (1930), a restraint for 15 years against alienation to persons of African descent was conceded to be valid in law; cquitablo relief was denied because of a change in conditions in the locality. One judge dissented on the ground that an injunction should bave been granted. In Chandler v. Ziegler, 88 Colo. 1, 291 Pac. 822 (1930), the plaintiff, who had purchased a lot in a subdivision, sued to recover damages for his vendor's misrepresentation that all lots in the subdivision wero restricted against alienation to non-Caucasians. It was held that, since such a restraint would have been valid, the plaintiff was entitled to damages.

181. White v. White, 108 W. Va. 128, 150 S. E. 531 (1929) (restraint for 50 years against alienation to persons of the "Ethiopian" race). There was a dictum in this casso that the term "Ethiopian" included negroes. In People's Pleasure Park Co. v. Rohleder, 109 Va. 439,61 S. E. 794 (1908), rehearing denied, 63 S. E. 981 (1908), a restriction against alienation to persons of African descent was held not to have been violated by a conveyance to a corporation composed of negroes. No opinion was expressed upon the validity of the restriction.

182. Los Angeles Investment Co. v. Gary, 181 Cal. 680, 186 Pac. 596 (1919) (forfelture restraint; see note 172 supra); Wayt v. Patee, 205 Cal. 46, 269 Pac. 660 (1928) (covenant for 25 years against occupancy by any person not of Caucasian race; negro transfereo enjoined from occupying); Littlejohns v. Henderson, 111 Cal. App. 115, 295 Pac. 95 (1931) (apparently a perpetual covenant against occupancy by persons of African or Asiatic races; relief as above); cf. Janss Investment Co. v. Walden, 196 Cal. 753, 239 Pac. 34 (1925) (contract to purchase land forfeited for breach of restriction against occupancy by nonCaucasians. See note 173 supra). 
upon occupancy may be classified in theory, in practice it is a restraint upon alienation in this type of case. Negroes and Asiastics, against whom the restriction is directed, are not likely to buy land which they themselves cannot occupy, and which they cannot even lease to members of their own race. The actual effect of the restriction is to exclude members of these races as potential purchasers of the land. ${ }^{183}$ Restraints upon occupancy, nevertheless, have been sustained in almost every case in which the problem has arisen. ${ }^{181}$ This state of the authority seems explicable only upon the supposition that the courts have believed the social interest to require the toleration of these restrictions, that they have felt precluded by supposed authority from upholding the restrictions when phrased directly as restraints upon alienation, but have eagerly seized upon the theoretical difference between a restraint upon alienation and a restraint upon occupancy to justify their conclusions.

Occasionally, religious prejudice may give rise to restrictions similar to those discussed above. Thus, in an Irish case, ${ }^{185}$ a provision requiring the payment of forty shillings additional ground rent for every acre of the demised land which might be occupied by a "Papist" was held valid, on the ground that it merely prevented alienation to particular persons as permitted by Littleton's exception. The court declared that it would not go into the question, what religion predominated in the community. The restraint was valid, therefore, though its practical efiect may have been to make alienation of the land impossible.

183. This distinction between the validity of a restraint upon alienation to the membors of a social group, and a restriction upon occupancy by such members, is exceedingly subtle. In Los Angeles Investment Co. v. Gary, 181 Cal. 680, 186 Pac. 596 (1919), the court felt bound to hold a direct restraint upon alienation invalid under Sec. 711 of the CaImorata CrvIl Code, which provided, "Conditions restraining alienstion, when repugnant to the interest created, are void." It has been suggested heretofore that no condition against alienation can accurately be said to be "repugnant." See text, supro, at note 90. In any event, this Code provision, which seems by clear implication to recognize sonac restraints upon alienation as valid, would seem vague enough in its meaning to parmit any decision that a court might feel inclined to reach. A condition agoinst occupancy would seem as much "repugnant" as one against alienation, since the practioal effect is the same. See remarks in Title Guarantee \& Trust Co. v. Garrott, 42 Cal. App. 152, 162, 183 Pac. 470, 474 (1919). The dissenting opinion in Los Angeles Trust Co. v. Gory indicates another point of criticism of the majority decision. Since the deed involved contained conditions against both alienation and occupancy, the latter condition would appar to have been inserted to prevent lease by a white owner to a member of the proscribed clucs, and to have no application to occupancy by an owner to whom a valid conveyance in fee could be made.

184. In addition to the California authorities, supra note 182: Parmalce v. Morris, 218 Mich. 625, 18s N. W. 330 (1922) (perpetual covenant against occupancy by negroes; nesto enjoined from occupying); Schulte v. Starks, 238 Mich. 102, 104, 213 N. W. 102 (1927) (covenant that premises would not be "sold, rented or lezsed to any person or clacs of persons whose ownership or occupancy would be injurious to the locality"; negro who understood that purpose of the restriction was to exclude persons of his race enjoined from occupying); and see White v. White, $10 \mathrm{~S}$ W. Va. 128, 130, 150 S. E. 531, 532 (1929). 185. Mahony v. Tynte, 1 Ir. Ch. R. 577 (1851). 


\section{Restraints Qualified as to the Mode of Alienation-Forfeiture for Failure to Alienate}

Alienation is a term sufficiently broad to cover various modes of transfer of property interests. There may be voluntary alienation by some act of an owner of property which is intended to effect a transfer of his interest. There may be involuntary alienation by a sale under judicial process to satisfy a debt due from the owner. Restraints against alienation are often broad enough in terms to apply to either of these two types; and, in general, the courts have not made a distinction as to the validity of restraints in the two situations. ${ }^{186}$ We shall here confine the discussion, therefore, to voluntary alienation.

Voluntary alienation may be subdivided into two principal types: transfer inter vivos, and transfer at death by will. Descent of property upon the death of the owner intestate could be regarded from one point of view as a form of alienation, since it effects a transfer of ownership. It cannot be viewed as voluntary alienation. For the purposes of this discussion it will not be considered as a method of alienation. ${ }^{187}$ Aliena-

186. See note 52, supra; Wieting v. Billinger, 50 Hun 324, 3 N. X. Supp. 361 (Sup. Ct. 1888). A restraint directed only against involuntary alienation is not a completo bar to alienation; indeed, a restraint thus limited presents no substantial impediment to transfer. It is, however, a general rule that whatever property a debtor may transfer, to that property a creditor may resort for satisfaction of his claim. A restraint which has for its sole purpose the defeat of a creditor seeking payment of an honest claim does not commend itself to one's sense of justice. In connection with disabling restraints upon equitablo life estates, which are valid almost everywhere in the United States, doubt has been expressed whether a restraint directed against involuntary alienation only is valid. See Eaton v. Boston Trust Co., 240 U. S. 427 (1916); Jones v. Harrison, 7 F. (2d) 461 (C. C. A. 8th, 1925). In Blackburn v. McCallum, 33 Can. Sup. Ct. 65 (1903), Taschereau, C. J., held void a restraint against involuntary alienation of a legal cstate, but refused to determine the validity of a restraint upon voluntary alienation. It may be noted in this connection that in several cases a restraint in general terms has been declared inapplicablo to involuntary alienation. Henderson v. Harness, 176 IIl. 302, 52 N. E. 69 (1898); Stowart v. Brady, $66 \mathrm{Ky} .623$ (1868); Auxier's Ex'x v. Theobald, $255 \mathrm{Ky}, 583,75 \mathrm{~S}$. W. (2d) 39 (1934). This rule is regularly followed in construing restraints imposed upon estates for years. See 1 Trfaniry, Landoord and Tenant (1912) § 152 (f). In Lynch v. Lynch, 161 S. C. 170,159 S. E. 26 (1931), a restraint in terms applicable to involuntary alienation only was sustained, with some emphasis upon the fact that the conveyee had a complete power of voluntary transfer. Cf. Hinshaw v. Wright, 124 Kan. 792, 262 Pac. 601 (1928); see Phillips v. Big Sandy Co., 32 Ky. L. Rep. 1262, 1263, 108 S. W. 276 (1908). In Dehorty's Lessee v. Jones, reported in note to Barnard's Lessee v. Bailey \& Kettlewood, 2 Harr. 56 (Del. 1836), the restraint upon voluntary alienation was conceded to be vold. There was also a forfeiture stipulated if the conveyee should "involve himself in debt to the amount of $£ 30$." The decision that the conveyee had forfeited the land for brcach of this condition appears to have been based on the theory that the condition was not at all a restraint upon alienation. The decision is clearly erroneous. So far as the effect upon a creditor is concerned, it is immaterial whether the debtor's property is removed from the creditor's reach when the debt is contracted, or only when he takes steps to realize payment through judicial process. 
tion inter vivos may take the form of an absolute transfer of all interest in the subject matter of the property; a transfer for purposes of security, as by mortgage; or a transfer of a limited interest, as a term of years. A restraint upon alienation may undertake to prevent all alienation; or it may be so limited in scope as to prohibit only alienation by particular modes of transfer.

A restraint which forbids all alienation inter vivos is a substantial impediment to transfer. If the restraint is for the life of the conveyee, it is a complete restraint for that length of time, even though the conveyee is allowed the power to devise. It is the power of inter vivos transfer which is practically important. It is usually held, therefore, that a restraint forbidding transfer inter vivos is void, though it be qualified to permit a devise. ${ }^{188}$ It is immaterial in what precise form the restraint may be cast, if its actual effect is to prevent inter vivos alienation. Thus, a gift over if the conveyee shall die without leaving a will devising the property is void; strictly interpreted, such a gift over makes it impossible for the conveyee to alienate by deed, since any transferee would be divested if the conveyee should die without having confirmed the deed by a

187. The fact that the land subject to the restraint upon alienation can descend upon the death of the owner intestate, does not in any way remove the objections to the restraint. The laws of descent do not operate until the death of the owner; the restraint may exist, therefore, during the whole life of the conveyee. If the restraint in terms is for a longer period than the life of the conveyee, the descent of the property to bis theirs does not make it marketable.

188. Restraints in the disabling form, but no weight given to the fact: Gold=mith v. Petersen, 159 Iowa 692, 141 N. W. 60 (1913); MrcCullough's Heirs v. Gilmore, 11 Pa. 370 (1849); Jauretche v. Proctor, $48 \mathrm{~Pa} .466$ (1865); Kauiman v. Burgert, 195 Pa. 274, 45 Atl. 725 (1900); MIartin v. MIartin, L. R. 19 Ir. 72 (1SS6); see MIcIntyre v. MicIntyre, 123 Pa. 329, 16 Atl. 783 (1889); cf. Barnard's Lessee v. Bailey \& Kettlewood, 2 Hurr. 56 (Del. 1836). Restraints in the forfeiture form: Bonnell v. MicLaughlin, $173 \mathrm{Cal}$. 213, 159 Pac. 590 (1916); Kessner v. Phillips, 189 Mio. 515, 88 S. W. 66 (1905). In a large number of the decisions holding restraints void, the language employed in the retraints did not expressly prohibit alienation by way of devise; this fact was evidently regardcd as unimportant.

In Comiskey v. Bowring-Hanbury, [1905] A. C. 84, the testator devised his whole estate to his wife in these terms: ".... absolutely in full confidence that she will malie such use of it as I should have made myself and that at ber death she will devise it to such one or more of my nieces as she may think fit and in default of any disposition thereof by her will or testament I hereby direct that all my eitate and property acquired by her under this my will shall at her death be equally divided among the surviving said nieces." The court construed this language to give the vife no power to transficr inter vivos, but only a power to devise to one or more of the nicces. It was held that she took a fee simple, with a valid executory devise to the nieces. Where the only powier of alienation allowed the first taker is a power of devise as narrowly limited as this one, it should not be difficult to infer the intent to create a life estate only, with a power to appoint by will, and a remainder limited in default of appointment. The interest of the wife was spoken of as a life estate in the opinion of James, L. J. See note $231 \mathrm{irs} / \mathrm{ra}$; Sweet, supra note 157 , at $253, \mathrm{n}$. 
testamentary provision. No purchaser would knowingly assume this risk. 189

A restraint may expressly or impliedly allow the conveyee to make leases. It is impossible to decide abstractly whether such a qualification should make the restraint valid. The problem is whether the restraint by a reasonable constructoin permits leases of a character that obviates the objection to a restraint upon alienation. If a long-term lease is permissible, which will make possible substantial improvements upon the land, it may be contended that the restraint should be held valid. Yet restraints have usually been held invalid, even though qualified to allow leases, without consideration of the kind of lease permitted. ${ }^{190}$

The Canadian rule in regard to restraints qualified as to the mode of alienation is contrary to the view above indicated. It seems to be an established rule there that a qualification as to mode may render a restraint valid. ${ }^{101}$ The precise extent of the qualification required is not at all clear from the cases. In all the decisions holding valid restraints qualified as to mode of alienation, the restraints have been limited in duration as well. ${ }^{192}$ In all instances devise by the conveyee was ex-

189. Moore v. Sanders, 15 S. C. 440 (1881); Holmes v. Godson, 8 De G. M. \& G. 152 (Ch. App. 1856). The decision in the latter case was actually put on the ground that it was contrary to the policy of the law to permit the devolution of property according to the rules of intestacy to be affected by a gift over which became operative at death. This point is considered more fully later.

190. Goldsmith v. Petersen, 159 Iowa 692, 141 N. W. 60 (1913); McFadden v. McFadden, 302 Ill. 504, 135 N. E. 31 (1922); Gischell v. Ballman, 131 Md. 260, 101 Atl. 698 (1917). The same conclusion was reached in Blackshere v. Trustees of Samucl Ready School, 94 Md. 773, 51 Atl. 1056 (1902), where the qualification permitted a ninety-nine year lease. Although restraints are rarely so phrased as to exclude definitely the power to lease, the existence of that power has seldom been discussed.

191. Re Winstanley, 6 Ont. Rep. 315 (Ch. 1884); O'Sullivan v. Phelan, 17 Ont. Rep. 730 (1889); Re Northcote, 18 Ont. Rep. 107 (Ch. 1889); Chisholm v. London \& Western Trust Co., 28 Ont. Rep. 347 (1897); Re Martin \& Dagneau, 11 Ont. L. R. 349 (1906); Re Porter, 13 Ont. L. R. 399 (1907); see Smith v. Faught, 45 U. C. Q. B. 484, 488 (1881); Meyers v. Hamilton Provident and Loan Co., 19 Ont. Rep. 358, 366 (1890). But cf. Heddlestone v. Heddlestone (see comment, infra note 193).

Blackburn v. McCallum, 33 Can. Sup. Ct. 65 (1903), decided in the Supreme Court of Canada, and previously discussed in connection with restraints limitcd in duration, did not directly involve the present problem, since the restraint in that case was completo for the period of its duration. The opinions rendered by the several judges seem to indicate differing views on the validity of a restraint qualified as to modo of alienation. Davies, J., in whose opinion Sedgewick, J., concurred, suggested (pp. 80-81) that such a restraint was valid if limited in time; Mills, J., was seemingly opposed to any and all restraints. Re Martin \& Dagneau, and Re Porter, suspra, were decided after Blackburm v. McCallum. Both decisions construed the latter case to have no effect upon the problem here discussed. See also the opinion of Magee, J. A., in Hutt v. Hutt, 24 Ont. L. R. 574 (1911).

192. In some of the earlier cases decided before Blackburn v. McCallum (sce noto 191 supra), the time limitation in itself may have been thought sufficient to make the restraint 
pressly ${ }^{193}$ or impliedly ${ }^{194}$ permitted by the terms of the restraints. And in every instance the court inferred, in addition to the power to devise, the further power to lease, or the power to mortgage. ${ }^{105}$ It is not certain, therefore, whether any one of these three powers is sufficient in itself to make a restraint valid. ${ }^{198}$ In some instances the restraints upheld were cast in the disabling form, but in no case was their disabling nature directly in issue. ${ }^{197}$ No authority can be found in this group of cases which sustains directly a disabling restraint.

The adoption of the Canadian doctrine raises some exceedingly dificult problems of construction. Does a restraint upon the "sale" of land prohibit only a transfer of a fee simple absolute by deed, leaving the conveyee free to devise, to mortgage, or to lease? In Re Macleay, ${ }^{109}$ the validity of the restraint was upheld principally upon the ground that it expressly allowed alienation within the family of the conveyor and conveyee. Sir George Jessell, in his opinion, however, made the additional point that the restraint against "sale" allowed a mortgage or a lease. While this view has been severely criticized in England, ${ }^{109}$ it has had great influence in Canada. ${ }^{200}$

valid. Since that decision, it seems clear that it is not enough. Re Martin \& Dagreau, 11 Ont. L. R. 349 (1906); Re Porter, 13 Ont. L. R. 399 (1906); Hutt v. Hutt, 24 Ont. L. R. 574 (1911). It appears likely that the Supreme Court of Canada, if it should sustain a restraint qualified as to mode, would hold a time limitation necessary. See comment, supra note 191, on the opinion of Davies, J., in Blackburn v. ZlcCallesm. But note also the remarks of Teetzel, J., in Re Porter, 13 Ont. L. R. 399, 402 (1907).

193. In Re Winstanley, 6 Ont. Rep. 315 (Ch. 1854), a complete power of testamentary disposition was expressly given. In Re Northcote, 1s Ont. Rep. 107 (Ch. 1859), a power to devise to children was stated; the court construed the power to devise as complete. In O'Sullivan v. Phelan, 17 Ont. Rep. 730 (1889), the restraint appeared to parmit a devise because there was also a gift over if the conveyee should die without leaving a will. In Heddlestone v. Heddlestone, 15. Ont. Rep. 280 (1888), the power of tetamentary disposition was limited to a devise to "heirs", and no form of inter vivos alienation was allowed; the restraint was here held void.

194. In the following cases the restraint made no espress mention of a power to devise, but the courts inferred it: Chisholm v. London \& Western Trusts Co., 23 Ont. Rep. 347 (1597); Re Martin \& Dagneau, 11 Ont. L. R. 349 (1906); Re Porter, 13 Ont. L. R. 399 (1907); see Smith v. Faught, 45 U. C. Q. B. 484, 488 (1881); Meyers v. Hamilton Provident and Loan Co., 19 Ont. Rep. 358, 366 (1890).

195. It may be noted that the restraints in O'Sullivan v. Phelan, 17 Ont. Rep. 730 (1889), and Smith v. Faught, 45 U. C. Q. B. 484 (1Ss1), were qualified not only as to time and mode of alienation, but also as to the alienee, permitting inter vivos transier by any method to a small class.

196. It is possible to infer from some of the decisions, particularly Re Winstanley, 6 Ont. Rep. 315 (Ch. 1884), that the power to devise would in itself be enough. See opinion of Proudfoot, J., at 329.

197. Re Winstanley, 6 Ont. Rep. 315 (Ch. 1884); Chisholm v. London \& Western Trusts Co., 28 Ont. Rep. 347 (1897); Re Mirtin \& Dagneau, 11 Ont. L. R. 349 (1905); Smith v. Faught, 45 U. C. Q. B. 484 (1881); Meyers v. Hamilton Provident and Loan Co., 19 Ont. Rep. 358 (1890).

198. L. R. 20 Eq. 186 (1875).

199. See In re Rosher, 26 Ch. D. 801, 817-820 (1884).

200. In Smith v. Faught, 45 U. C. Q. B. 484 (1881), and in Ireyers v. Fiamilton 
This interpretation of a restraint against "sale" seems unsound, especially as respects the power to mortgage. It is unreasonable so to construe a restraint that the conveyee can evade it by the simple expedient of mortgaging the land for the largest possible sum, and then defaulting in payment of the mortgage..$^{201}$ As to a lease, the solution is more doubtful. Clearly the conveyee is intended to have enjoyment of the land, and it might appear unreasonable to interpret the restraint to require his personal occupancy. The purpose of the restraint, however, might be defeated by a long-term lease; ${ }^{202}$ this fact may argue for an interpretation which will prohibit any lease. ${ }^{203}$ The difficulty of these construction problems reffects further doubt upon the utility of a rule which makes the validity of a restraint depend upon the fact that every possible mode of alienation inter vivos has not been forbidden.

Frequently a conveyor limits land over on the death of the conveyee without having disposed of the same during his lifetime. In such a case there is no express restraint upon alienation, and it is clear that the conveyee has entire freedom to convey by deed. The language employed, however, may deny the power to transfer by means of a will, which is one mode of alienation. ${ }^{204}$ This kind of a restraint seems practically

Provident and Loan Co., 19 Ont. Rep. 358 (1890), a restraint on "sale" was declared to allow a devise, a mortgage, or a "gift." In Re Martin and Dagneau, 11 Ont. L. R. 349 (1906), and Re Porter, 13 Ont. L. R. 399 (1906), a restraint upon "mortgage" or "Ealo" was said to permit a devise or a lease. Contra: Re Shanacy and Quinlan, 28 Ont. Rep. 372 (1897). In Chisholm v. London and Western Trusts Co., 28 Ont. Rep. 347 (1897), a restraint upon "disposal" was held to prohibit a mortgage, but was regarded as parmitting a devise or a lease. Cf. Re Winstanley, 6 Ont. Rep. 315 (Ch. 1884); Earls v. McAlpine, 6 Onit. App. 145 (1881). A condition that the conveyee never "will" tho land, or "make away with it, by any means, but keep it for his heirs", was held unquallfied as to mode of alienation, and therefore void in Re Watson and Woods, 14 Ont. Rep. 48 (Ch. 1887).

201. See In re Rosher, 26 Ch. D. 801,819 (1884).

202. In Voris v. Renshaw, 49 Ill. 425 (1867), it was held that a restraint for ton years, which expressly allowed a "lease for a term of years", was not violated by tho making of a lease for 99 years.

203. Note 201, supra.

204. The power to alienate by deed is allowed, and the power to transfer by will is denied, where the language employed, in substantial effect, limits a gift over, to como into possession at the death of the first taker, and to include: "any unexpended remainder"; "whatever part may remain"; "whatever part may then be owned (possessed, held)"; "any part that may remain undisposed of". Language in the form last quoted might arguably be held to give a power to devise as well as to convey by decd, but it sccms more reasonable to infer from it a power to convey by deed only. Doe d. Stevenson v. Glover, 1 C. B. 448 (1845); Vincent v. Rix, 248 N. Y. 76, 161 N. E. 425 (1928). But see Kales, Estates, Future Interests, etc. IN InLINors (2d ed. 1920) \& 717; see also noto 227 , infra. Where the gift over is of the "remainder", and no words of inheritanco bavo been used in the limitation to the first taker, it might reasonably be contended that ho should take only a life estate, with a remainder in fee limited thereupon. It was held, however, in Mitchell v. Morse, 77 Me. 423, 1 Atl. 141 (1885), that a fee was created, with a void gift over. But cf. Gahan v. Golden, 330 Ill. 624, 162 N. E. 164 (1928); Galligan v. McDonald, 200 Mass. 299, 86 N. E. 304 (1908). 
innocuous, as it does not produce actual inalienability for any period of time whatsoever. By hypothesis, the conveyee has absolute power to alienate by deed during his lifetime; he may not devise the land, but it will pass at his death by force of the gift over, to the donee designated therein, and the latter will at once have an absolute power to transfer.9s The forfeiture in this situation is for failure of the conveyee to alienate by deed. While the decisions have almost unanimously held these gifts over invalid, ${ }^{206}$ they are not usually based upon the proposition that such gifts restrain alienation by will, but rather upon other grounds, discussed below, which have no reference to restraints upon alienation.

Closely allied to the class of limitations above discussed is another, in which a gift over is conditioned upon the death of the conveyee without having disposed of the property by either deed or will. ${ }^{207}$ In this type of case, there is no restraint whatsoever upon alienation, since the conveyee is given complete power to transfer by any method he may choose to employ. Here also the gift over is held void..$^{208}$

205. Professor Gray thought that such a gift should be beld void as a restraint on alienation by will. Restramps UpoN the Alnevation of Propersty (2d ed. 1895) $\S 56$. Mr. Kales apparently took the same view. Op. cit. stppra note 204, \& 719. Other writers, however, have failed to perceive any objectionable restraint upon alienation in this caes. See Page on WiLls (2d ed. 1926) 1806, n. 4; White, Restraints on Alicnation, ctc. (1928) 2 U. OF CIN. L. REv. 333, 344.

206. Shaw v. Ford, 7 Ch. D. 669 (1877); Sweet v. Arnold, 322 Ill. 597, 153 N. E. 746 (1926); Case v. Dwire, 60 Iowa 442, 15 N. W. 265 (1883) (note the dissenting opinion); Meyer v. Weiler, 121 Iowa 51, 95 N. W. 254 (1903) (note the disent); Roth v. Rauschenbusch, 173 Mo. 582, 73 S. W. 664 (1903); Benz v. Fabian, 54 N. J. Eq. 615, 35 Atl. 760 (1896); Rhode Island Hospital Trust Co. v. City of Woonsocket, 48 R. I. 345, 137 Atl. 411 (1927); Skinner v. Skinner's Adm'r, 158 Va. 326, 163 S. E. 90 (1932); cf. Res v. Bell, $147 \mathrm{~Pa}$. 118, 23 Atl. 349 (1892) (inter vivos transfer restricted to one parson). Contra: Krause v. Krause, 113 Neb. 22, 201 N. W. 670 (1924). See note 223, infru.

207. Writers have often described gifts of this kind as "Gifts Over upon Intestacy." See Gray, op. cit. supra note 205, at 48 . The writer regards this description as unfortunate, since it involves an ambiguity. Professor Gray intended it to deseribe a gift conditioned on a failure to alienate either by deed or by vill. The description, however, may be taken to indicate a gift conditioned merely upon the death of the conveyee without leaving a will devising the property. A gift over thus conditioned restrains alienstion inter vivos, and is clearly void. See text supra, at note 189; and see note 225 , infra.

208. Ross v. Ross, 1 Jac. \& W. 154 (Rolls 1819); Howard v. Carusi, 109 U. S. 725 (1884); Jackson v. Robins, 16 Johns. 537 (N. Y. 1819); Wolfer v. Hemmer, 144 III. 554, 33 N. E. 751 (1893); Foster v. Smith, 156 IIass. 379, 31 N. E. 291 (1892); Crutchfidd v. Greer, 113 Va. 232, 74 S. E. 166 (1912). There was early authority in Ifaceachusotts to the contrary. Hubbard v. Rawson, 70 Mass. 242 (1855); and see Grar, op. cit. suffos note $205, \S \S 72-72 a$. In Overton v. Lea, 108 Tenn. 505, 68 S. W. 250 (1902), a tectator devised the residue of his property to M, with a gift over if she should dic "intectate", or if she should "give" or "bequeath" any portion of the property to either of two mamed persons or their descendants. The Tennessee court held the gift over valid in its entirety". Emphasis was put upon the fact that the restraint upon alienation was directed againat transfer to particular persons only. This case seems irreconcilable with the earlier deciaion in Williams v. Jones, 32 Tenn. 620 (1853).

In some instances language referring to disposition of property at the death of the first 
The futility of the reasons commonly assigned to explain the invalidity of a forfeiture for failure to alienate has been so completely demonstrated by Professor Gray, in his well known book, Restraints upon Alienation, that it does not seem necessary to discuss the problem here in detail, or to assemble a large collection of authorities. ${ }^{200}$ Since no restraint upon alienation worthy of mention is involved, the topic is in a measure beyond the scope of the writer's subject. It has, however, usually been discussed in connection with restraints upon alienation; for that reason it may be expedient to indicate the extent to which the courts have carried the rule, and the general state of the authority.

In respect to personal property, there is found in the earlier English decisions a reason of some weight for the invalidity of a gift over on failure to alienate by deed or by will. In many instances it will be very difficult to determine whether any of the original personalty remains in specie at the death of the first taker, particularly where it consists of money. This vexatious problem is eliminated by the rule that the gift over is void. ${ }^{210}$ This reason never had application to gifts of land, and it has now been lost to sight entirely. ${ }^{211}$ The decisions, with respect to both personalty and realty, are now based upon one or another of three grounds: first, that the gift over is logically inconsistent, or "repugnant"; second, that devolution of property according to the laws of intestacy is an incident of an estate in fee, interference with which is forbidden by considerations of public policy; third, that an executory limitation over which can be defeated by the first taker is void. ${ }^{212}$

The first ground, "repugnancy," seems to be that there is a logical inconsistency between the conveyance of a fee simple and a limitation over which will prevent that fee from descending in the normal way upon the death of the conveyee intestate. It is difficult, however, to perceive any inconsistency. If the fee is created as a defeasible fee, then it does not have all the characteristics of a fee simple absolute. Fees defeasible upon conditions are quite common-e.g., a fee which is limited over on the death of the first taker without issue surviving. Such a limi-

taker may properly be construed to express merely a desire as to what disposition the first taker shall make, and not to constitute a gift over. Second Reformed Presbyterian Church v. Disbrow, 52 Pa. 219 (1866). This construction has been relied upon in other cases where its propriety is, at least, doubtful. Bills v. Bills, 80 Iowa $269,45 \mathrm{~N}$. W. 748 (1890); Bradford v. Martin, 199 Iowa 250, 201 N. W. 574 (1925); Tillman v. Ogren, 227 N. X. 495,125 N. E. 821 (1920). Occasionally the language limiting the gift over is characterized as "precatory" when it is clear that the term cannot be used in its literal sense. Hambel v. Hambel, 109 Iowa 459, 80 N. W. 528 (1899). In Merrill v. Pardun; 125 Neb. 701, 251 N. W. 834 (1933), a "request" that property remaining at the death of the first taker be disposed of in a certain way was held to limit a valid remainder and to give the first taker a life estate only.

209. Op. cit. supra note $205, \S \S 57-74$ g.

210. Watkins v. Williams, 3 Mac. \& G. 622 (1851); GrAy, op. cit. supra note 205, of 58 .

211. GraY, op. cit. supra note $205, \S \S 58-59,62$.

212. Id. \& 74c. 
tation over is undoubtedly valid, although it will operate to prevent descent of the fee according to the laws of intestate succession if the condition occurs. ${ }^{213}$ Inheritability, therefore, is not an essential element in the concept of a legal fee simple.

The second ground of invalidity differs from the first in that it emphasizes, not conceptual inconsistency, but rather a public policy against the validity of a gift which interferes with descent in event of a failure to alienate; a policy, as expressed by one judge, ${ }^{211}$ which recognizes that the right to enjoy without alienation is as much an incident to the estate as the right to alienate it. It may be questioned, however, whether there is any such public policy. The public policy against recognition of restraints upon alienation is understandable, even though one may believe that the rules developed are unnecessarily stringent. A gift over on failure to alienate, since it encourages alienation, does not conflict with this public policy. One cannot at this day comprehend any definite societal advantage which will accrue from the descent of the land to the heir, but not from its passage to another by force of an executory limitation. The fact that executory limitations over on death without issue, and others of like sort, are freely recognized, proves that there is no such advantage. If there is any real objection to a gift over on a failure to alienate, it is based upon a public policy which is not made explicit in the modern cases. In only one situation can even the possibility of such a policy be perceived. Where the gift over is conditioned solely on failure to alienate by deed, it may be contended with some plausibility that the limitation over encourages a wasteful use of the property by the first taker, since the gift over deprives him of the power to devise the property, and prevents its passing at his death to his heirs. ${ }^{210}$ In the endeavor to use it up during his lifetime, the conveyee may employ it in a manner not useful either to himself or to society. This contention, however, seems much exaggerated. The conveyee can transfer by deed to his presumptive heirs, and thus put them in substantially the same position as if there were no limitation over.

The third ground of invalidity is that an executory limitation which is destructible at the will of the first taker is void. This idea probably arose from a miscomprehension of the well established rule that an executory limitation, unlike a contingent remainder, is indestructible by any act on the part of the first taker. ${ }^{210}$ It does not follow, however, that the

213. Id. § 63; PaGE, loc. cit. supra note 205; and see also remarks upon "repugnancy" as an explanation for the invalidity of restraints, supra, subtitle $\Pi, B$.

214. Mr. Justice Fry, in Shaw v. Ford, 7 Ch. D. 669, 674 (1877).

215. Watkins v. Williams, 3 Mac. \& G. 622 (1851); Gray, op. cit. sufru note 205, $\S 58$. See also the suggestion of another possible objection, id. § 74g.

216. GrAY, op. cit. supra note $205, \S 69$. This ground of invalidity is the one now usually relied upon; while the word "repugnancy" is often employed, it is used in a sence different from that explained in the text suprd. See.also, 1 TrFasry, REL Prormiry (2d ed. 1920) § 167. 
first taker may not be given an express power which will enable him to defeat the executory limitation. In the cases now under discussion, moreover, the first taker does not always have a complete power of destruction. If he can transfer only by deed inter vivos, he cannot destroy the executory limitation by a testamentary disposition. Even this qualified power of destruction, however, is sufficient to invalidate the limitation over. ${ }^{217}$ It seems clear that this third reason for the invalidity of a gift conditioned on failure to alienate is no more convincing than those previously discussed. There is no real reason why the power of the first taker to destroy the limitation over should make the latter invalid. ${ }^{218}$ Indeed, the policy of the law argues directly for a contrary conclusion. An indestructible future interest may be valid even though it presents a substantial impediment to alienation. A fortiori, one which, being destructible, offers no impediment whatsoever, should be valid.

The unsoundness of the rule that a gift over on failure to alienate is void, appears even more clearly where the gift over is upon the combined contingencies of death without issue surviving, and failure to alienate. A limitation over on death without issue surviving, standing alone, is unquestionably valid. Since it is necessarily contingent until the death of the first taker, it imposes an effectual check upon alienation during his lifetime. Any added contingency which will have the effect of removing this impediment to alienation ought not to make the gift over void. With this general premise in mind, we may consider the various ways in which the contingency of death without issue may be combined with the contingency of a failure to alienate. First, there may be a gift over on the double contingency of death without issue and a failure to convey by deed. This combination of contingencies, by the clearest kind of implication, ${ }^{219}$ allows to the first taker the power by an alienation in his lifetime to destroy the executory limitation over on death without issue surviving, which by itself would produce inalienability. In a legal sys tem in which alienability of property is regarded as highly important and desirable, one would suppose that a gift thus limited, which insures practical alienability, would be valid. The American authority, however, is contra. ${ }^{220}$

217. See authorities supra note 206.

218. GraY, op. cit. supra note $205, \S \S 69,70,74 \mathrm{~b}, 74 \mathrm{c} ; 1$ TrFaNY, loc. cit. supra noto 216 .

219. The implication of a power of disposal is clear even though it be not stated in express words. See note 204, supra.

220. Tarbell v. Smith, 125 Iowa 388, 101 N. W. 118 (1904); Morrill v. Morrill, 116 Me. 154, 100 Atl. 756 (1917); Ide v. Ide, 5 Mass. 500 (1809); Galligan v. McDonald, 200 Mass. 299, 86 N. E. 304 (1908) ; Bennett v. Association, etc. for Friendless, 79 N. J. Eq. 76, 81 Atl. 1098 (1911); Van Horne v. Campbell, 100 N. Y. 287, 3 N. E. 316 (1885); Hambright v. Carroll, 204 N. C. 496, 168 S. E. 817 (1933); Bing v. Burrus, $106 \mathrm{Va}$ 478, 56 S. E. 222 (1907); cf. Vaubel v. Lang, 81 Ind. App. 96, 140 N. E. 69 (1923); Howe v. Howe, 94 Kan. 67, 145 Pac. 873 (1915). Such a gift over was held valid in Doe d. Stevenson v. Glover, 1 C. B. 448 (1845); see Kares, loc. cit. supra noto 205. 
Second, there may be a gift over on the double contingency of death without issue and a failure to convey by deed or by will. Here again, the combination of contingencies assures complete alienability; the overriding power of the first taker to destroy the executory limitation is absolute. The rule adopted for the first situation, however, is applied here also, and the gift over is held void. ${ }^{221}$

Third, there may be a gift over on the double contingency of death without issue and failure to alienate by will only. In this situation, the first taker does not have the power to destroy the executory limitation by a transfer by deed. In practice, however, there is no greater inalienability than would result from the single contingency of death without issue. A gift limited over on that single contingency would be valid. It would seem, therefore, that a gift on this combination of contingencies ought to be valid. At this point, the decisions are in conflict.

This conflict of authority is surprising. Since this third combination of contingencies is the most objectionable, from the point of view of restraints upon alienation, of the three situations just discussed, one would suppose that the same rule would have been applied as in the two preceding instances. At the same time, the conflict of authority is significant of a certain judicial attitude torard the rule that invalidates a gift over on death of the conveyee without having alienated in his lifetime. The lack of reason in that rule has been indicated. It is, nevertheless, a firmly established rule, and little dissent can be found in express language. ${ }^{223}$ The attack upon it has taken the form of an

221. Williams v. Elliott, 246 Ill. 548, 92 N. E. 960 (1910); Combs v. Combs, 67 Mfd. 11, 8 AtI. 757 (1SS7). The authorities cited supra note 208 are equally partinent here.

222. That the gift over is invalid: Wilson v. Wilson, 268 Il. 270, 109 N. E. 36 (1915); Fisher v. Wister, $154 \mathrm{~Pa}$. 65, 25 Atl. 1009 (1593). The same conclusion was reached by the Supreme Court of New Jersey in Armstrong v. Kent, 21 N. J. L. 509 (184S), and its viev was adopted by the Chancellor. See Armstrong v. Kent, 6 N. J. Eq. 559 (1847). Contra: Hall v. Robinson, 56 N. C. 348 (1857) ; Andrews v. Roye, 12 Rich. I. 536 (S. C. 1860). Compare the decision of the New Jersey Court of Errors and Appeals in Armstrong v. Kent, 6 N. J. Eq. 637 (1850).

223. The rule is apparently repudiated in Krause v. Krause, 113 Neb. 22, 201 N. W. 670 (1924), although some of the language of the opinion suggests that the court regarded the gift as creating a life estate only, with a powier to convey by deed. See note 231, infru. The South Carolina court was strongly inclined to repudiate the rule in toto in Andretrs v. Roye, 12 Rich. L. 536 (S. C. 1860), but actually based its decision upon the ground indicated infra note 225. Doubt was also cast upon the rule in Hall v. Rotincon, s6 N. C. 348 (1857), and in Eaton v. Straw, is N. H. 320 (1846). See alio the disserting opinion in Case v. Dwire, 60 Iowa 442, 15 N. W. 265 (1S83).

In states having the New York real property legislation, courts bave now found in tha statutes a provision affording an escape from the rule. See Leggett v. Firth, $132 \mathrm{~N}$. Y. 7, 29 N. E. 950 (1892); Vincent v. Rix, 248 N. Y. 76, 161 N. E. 425 (1928); will of Zweifel, 194 Wis. 428,216 N. W. 840 (1927). See, however, Tillman v. Ogren, 227 N. Y. 495, 125 N. E. $\$ 21$ (1920), and comment thereupon in Whiteside and Edelstein, Lisc Estates with Power to Consume (1931) 16 Cors. L. Q. 447, 450-453. There is an expres 
undermining process, producing exceptions more weird than the original rule. The cases which evolved the rule declared it to be applicable only where the overriding power of disposal conferred upon the first taker was "absolute". The power usually given is a complete power to destroy the executory limitation by deed, and that is regularly held to be "absolute".224 Rather rarely, a gift over is conditioned on a failure to convey by will, thus allowing the power to destroy the limitation over only in that manner. If no other contingency were included, there would be a clear restraint upon alienation by deed, and the gift over would be void. Where, however, the gift over is on the double contingency of death without issue and a failure to devise, the denial of the power to transfer absolutely by deed causes no greater inalienability than would result from the single contingency of death without issue, which, for all practical purposes, deprives the conveyee of the power to transfer by deed. In this unusual situation, a court unsympathetic with the rule that invalidates a destructible gift over can easily avoid its application by declaring the power to devise not "absolute", and thus taking

abrogation of the common law rule in West Virginia. W. VA. CoDE (1931) c. 36, art. 1. With respect to difficulties arising from the failure to differentiate in such a statute between limitations of realty and personalty, see Comment (1931) 37 W. VA. L. Q. 422. See also note 231 , infra.

In Mlinois a unique doctrine has been developed, which had its origin in Fricdman v. Steiner, $107 \mathrm{Ill} .125$ (1883). In that case, $\mathrm{T}$ had devised all the residue of his property to $\mathrm{W}$, "to the total exclusion of any and all person or persons whalsoever: Provided, houever, upon the express condition . . . . in case the said (W) . . . shall die intestate and without leaving her surviving lawful issue . . . .", the property should go over. It was held that W took a "fee determinable", and in addition thereto an unlimited power of alienation in fee simple; and that the gift over was valid. In Williams v. Elliott, 246 IIl. 548, 92 N. E. 960 (1910), the devise was to N, "but in case the said (N) shall not dispose of the said estate devised to her, by will or otherwise, before her death, and should she die without issue, seized of said estate" the same should go over. It was here held that $\mathrm{N}$ had an unqualified power of disposal "as owner of the estate", and that the gift over was void. See Kales' statement of the rule thus evolved, op. cit. supro note $204, \S 725$. The mere statement of this curious rule gives no clue to its application in a particular case. It would appear from the decisions that two factors are of importance in the decision of the question whether a "fee determinable" has been created for the purposes of this rule. Language of condition employed in the limitation of the cstate is regarded as indicative of the intent to create such a fee; the gift in express terms of a power to alienate may also be significant. Cf. Forbes v. Forbes, 261 Ill. 424,104 N. E. 1 (1914). By way of further criticism of this rule, it may be remarked that it gives to the term "determinable fee" a quite different meaning than its usual one; that it makes the validity of the gift over depend upon language, the choice of which must almost certainly be purely accidental, since it can scarcely be imagined that the avcrage draftsman is familiar with this impractical distinction. It would be better to apply the orthodox rule with all of its vices than to attempt the distinction embodied in this Illinois rulo. The latter, in its practical effect, means that every case in which the form of langunge deviates slightly from the precedents must go to the Supreme Court for decision, with no predictability as to the final result.

224. Notes 206, 217, sutpra. But cf. Terry v. Wiggins, 47 N. Y. 512 (1872). 
the case out of the established formula. No inalienability results from the decision. A few courts have held, therefore, that the gift over on the double contingency of death without issue and failure to devise is valid, and yet have preserved ostensible adherence to the regular rule. ${ }^{\mathrm{gas}}$ When, however, a gift is limited on the single contingency of a failure to devise, the case is quite different. The fact that the overriding power is exercisable by will only makes it impossible for the first taker to pass an absolute title by deed, and thus renders the property inalienable. The case is, therefore, squarely within the rule invalidating any gift over, the primary purpose of which is to restrain alienation during the life of the first taker. This explanation probably accounts in large measure for the conflict of authority mentioned above. Following the theory discussed, that a power to devise only is not an "absolute" pover, some courts have gone to the length of holding that the gift over on failure of issue is valid if the only power of disposal conferred is a narrowly limited power to convey by deed, ${ }^{220}$ or a narrowly qualified power to transfer by will. . $^{27}$

These modifications of the common rule have an astonishing consequence. The rule, in holding invalid a gift over on death of the conveyee without issue and without having alienated, was irrational, because the

225. Andrews v. Roye, 12 Rich. L. 536 (S. C. 1860); Hall v. Robincon, 56 N. C. 343 (1857). In both of these cases, the gift over was conditional on death "intestate" and without issue. In both cases the courts construed the limitation over to give the first taker only a power to transfer by will. The same effect was given to the rord "intestate" in Moore v. Sanders, 15 S. C. 440 (1881), and Armstrong v. Kent, 21 N. J. L. 509 (1843). A strict construction might justify this conclusion. It may well be contended, horever, that a conveyor is not likely to speak of the conveyee as dying "intestate" with respact to land that he, the conveyee, has already conveyed; that dying "intestate" means dying without having disposed of the property by an inter vivos conveyance, and without havin: left a will devising it. See note 207 supra; Kares, op. cit. supra note $204, \$ 713$.

226. Woods v. Seymour, 350 ㄲll. 493, 183 N. E. 458 (1932).

227. Defrees v. Brydon, 275 Ill. 530, 114 N. E. 336 (1916); Eaton v. Straw, 18 N. H. 320 (1846). See dissenting opinion in Meyer v. Weiler, 121 Iowa 51, 95 N. W. 254 (1903). Cf. Terry v. Wiggins, 47 N. Y. 512 (1872).

The application of the common rule can be avoided, not only by finding the porser of disposal to be qualified, but also by finding that no power of disposal has been conferred. This is especially easy where the only power of disposal is such as an be inferred from the terms of the gift over. For examples of language usually construed to imply a power of disposal, see note 204, supra. In Smith v. Bedell, 349 Ill. 523, 182 N. E. 622 (1932), the court refused to imply a power of disposal in the first taker from language limiting over "the remainder of the property" on death without children, explaining the phrace quoted on the ground that it referred to natural depreciation of the personalty included in the devise. See also Andrews v. Roye, 12 Rich. L. 536, 545 (S. C. 1860). In this way the gift over may be saved, possibly at the expense of the first talier, who may have been intended to have the power of disposal. It may be noted that the question in Smith v. Bedell arose after the death of the first taker. The Illinois court has held, however, that a gift over of "any unexpended remainder" confers an absolute power of disposition. Sweet v. Arnold, 322 III. 597, 153 N. E. 746 (1926). 
inclusion of the latter contingency eliminated the inalienability that would have resulted from the former contingency standing alone. The rule did, however, preserve alienability, since the first taker was held to have a fee simple absolute. The modifications of the rule save the gift over only when the power of disposal is qualified, and not "absolute". Any qualification of the power of disposal actually diminishes the probability of alienation. Qualification of a power to transfer by deed may make alienation practically impossible. The modification of the rule, therefore, saves the gift over only when the possibility of alienation is least. Thus have technical rules obscured considerations of public policy, and culminated in unreasonable and absurd results.

The absolute futility of the doctrine of the invalidity of gifts over upon failure to alienate is demonstrated by attention to the fact that it is quite simple for a sufficiently skilled draftsman to accomplish the purpose of these gifts by another device. It is a well established rule that a life tenant may be given a power to appoint the remainder in fee either by deed or by will; and that the remainder may be limited over by the conveyor, subject to this power. In the great majority of jurisdictions, the grant of such a power does not enlarge the life estate to a fee simple. ${ }^{228}$ By this means, therefore, the conveyor may effect substantially the result which is denied where a fee is limited initially, with a gift over of so much as may remain undisposed of by deed or will at the death of the first taker. The conflict of these two opposing doctrines has occasioned an enormous mass of litigation, ${ }^{220}$ and the development of highly technical rules for determining whether a life estate or a fee has been given to the first taker. ${ }^{230}$ Where rules become

228. Hamlin v. U. S. Express Co., 107 Ill. 443 (1883) ; Healy v, Eastlake, 152 IIl, 424, 39 N. E. 260 (1894); Stuart v. Walker, 72 Me. 145 (1881); Loosing v. Loosing, 85 Neb. 66, 122 N. W. 707 (1909) ; Armstrong v. Kent, 6 N. J. Eq. 637 (1850); Chewning v. Eason, 158 N. C. 578,74 S. E. 357 (1912). The power of disposal may be implied where the limitation over after an express life estate is of what "may remain unexpended." In re Estate of Cashman, 134 IIl. 88, 24 N. E. 963 (1890); cf. Vanata v. Carr, 223 Ill. 160, 79 N. E. 86 (1906). A fortiori, a qualified power to transfer by deed does not enlarge the life estate to a fee. Rock Island Bank and Trust Co. v. Rhoades, 353 I11. 131, 187 N. E. 139 (1933); In re Estate of Proctor, 95 Iowa 172, 63 N. W. 670 (1895); Terry v. Wiggins, 47 N. Y. 512 (1872). See 1 TIFFANY, op. cit. supra note 216 at $80-81$; Restatement, Property (Tent. Draft \$3, 1929) $\S 155$.

By a minority rule followed in a few states, the grant of an absolute power of disposal does enlarge a life estate to a fee. Even in these jurisdictions, however, a qualified power does not have this effect. A power to transfer by devise only was held to be such $\mathfrak{a}$ qualified power in Magevney v. Karsch, 167 Tenn. 32, 65 S. W. (2d) 562 (1933).

229. GRAY, op. cit. supra note $205, \S \S 74 \mathrm{~d}-74 \mathrm{e}$.

230. The problem is most difficult in those cases in which the limitation to the first taker is indefinite as to the quantum of the estate conveyed. The decisions are in conflict, some holding that in such a case the grant to the first taker of an absolute power of disposal gives him a fee. Hambel v. Hambel, 109 Iowa 459, 80 N. W. 528 (1899); Skinncr v. Skinner's Adm'r, 158 Va. 326, 163 S. E. 90 (1932). In other jurisdictions, however, 
overly technical, it is to be expected that courts will slip in applying them to new cases, or, to express the idea more realistically, that they will select erroneously from the competing analogies at hand. There seems little doubt, too, that through lack of sympathy with the rule invalidating the gift over which is destructible by act of the first taker, the courts have gone far to find life estates with powers of disposal, where a more rational construction of language would lead to the inference of a fee simple. ${ }^{231}$

\section{III}

\section{Restratnts Upon the Alienation of Present Life Estates oR TERMS OF YEARS}

There are several reasons why a restraint upon the alienation of a legal life estate might be upheld. A life estate is not readily marketed; it is not likely to be transferred unless joinder of the remainderman can be procured. The restraint, therefore, does not cause much greater inalienability than would otherwise exist.

The restraint upon alienation, moreover, operates to protect the interest of the reversioner or remainderman. While there are rules that tend to protect the owner of a future interest against acts on the part of the life tenant which effect permanent injury to the land, these rules do not insure proper use thereof, or adequate recompense to the owner of the future interest for possible harm. The conveyor may reasonably believe that the particular life tenant to whom he has conveyed will have a due regard to the rights of those entitled in remainder or reversion, but he cannot be sure that an assignee of the life estate will exercise a similar consideration. A legally effective restraint upon alienation of the life estate adds materially to the protection of the future interest against waste, or other prejudicial conduct on the part of the present

such a limitation is construed to give the first taker a life ectate only, with a power of disposal. City of Little Rock v. Lenon, 186 Ark. 460, 54 S. W. (2d) 287 (1932); Hamlin v. U. S. Express Co., 107 III. 443 (1883); Bramley v. White, 281 Miass. 343, 183 N. E. 761 (1933). See Kales, op. cit. supre note $204 \& 168$. See also infro, subtitle V.

231. Where the gift to the first taker contains words of inheritance, or other language descriptive of a fee simple, it is usually held that he takes a fee, and the gift over, baing a destructible executory limitation, is void under the usual rule. Even in this situation, however, it has occasionally been held that the first taker has only a life estate with a power of disposal: Merrill v. Pardun, $125 \mathrm{Neb}$. 701, $251 \mathrm{~N}$. W. $\$ 34$ (1933); Stanton v. Guest, 285 Pa. 460, 132 Atl. 529 (1926); Roberts v. MLosely, 100 Fla. 267, 129 So. 835 (1930); cf. Burnett v. Piercy, 149 Cal. 178, 86 Pac. 603 (1906). By the simple expadient of construing an express limitation in fee to be a life estate only, with a power of dispa:3l, these courts have annihilated the rule that a gift over on failure to alienate is void. The construction above mentioned is reached more easily where the power of disposition is limited to a transfer by will only. Armstrong v. Kent, 6 N. J. Eq. 637 (1850). cf. Comiskey v. Bowring-Hanbury, [1905] A. C. 84. 
occupant, by keeping the life estate in the hands of a responsible individual. ${ }^{232}$

A life estate is commonly given for the purpose of providing the life tenant a means of support. If he can alienate the life interest and spend the proceeds of sale, that purpose is likely to be defeated.

It has been stated previously that the courts of equity have gone far in effectuating the conveyor's purpose to provide support, admitting even the validity of a disabling restraint when imposed upon an equitable life estate. There is no sufficient reason why the spendthrift trust doctrine should be extended to permit a disabling restraint upon a legal life estate. The disabling restraint is more obnoxious to public policy when imposed upon a legal interest; the likelihood that creditors will rely upon the ownership of the legal life tenant, who is usually in possession of the land, is great. If such disabling restraints must be tolerated, they ought to be confined narrowly within the equitable sphere. ${ }^{233}$ By the great weight of authority, a disabling restraint upon a legal life estate is void.9.94 In a very few jurisdictions, such restraints are valid. ${ }^{235}$

232. A forfeiture provision will normally induce retention of the land by the lifo tenant, whether the forfeiture is to the remainderman or to another person.

233. See Introduction, supra; footnotes 19-22.

234. Gray v. Shinn, 293 ㄱl. 573, 127 N. E. 755 (1920); Randolph v. Wilkinson, 294 IIl. 508, 128 N. E. 525 (1920); Thompson v. Murphy, 10 Ind. App. 464, 37 N. E. 1094 (1894); McCleary v. Ellis, 54 Iowa 311, 6 N. W. 571 (1880); McCormick HarvestingMachine Co. v. Gates, 75 Iowa 343, 39 N. W. 657 (1888); Brock v. Brock, 168 Ky. 847, 183 S. W. 213 (1916); Blackstone Bank v. Davis, 38 Mass. 42 (1838); Wellington v. Janvrin, 60 N. H. 174 (1880); Jones v. Jones, 28 Misc. 421, 59 N. Y. Supp. 974 (Sup. Ct. 1899) (personalty); Mizell v. Bazemore, 194 N. C. 324, 139 S. E. 453 (1927); Toledo Loan Co. v. Larkin, 25 Ohio Cir. Ct. 209 (1903); Ehrisman v. Sener, 162 Pa. S. C. 577, 29 Atl. 719 (1894); Verdier v. Youngblood, Rich. Eq. Cas. 220 (S. C. 1832) (personalty); Scruggs v. Murray, 70 Tenn. 44 (1878); Kerns v. Carr, 82 W. Va. 78, 95 S. E. 606 (1918); Bridge v. Ward, 35 Wis. 687 (1874); West Tenessee Co. v. Townes, 52 F. (2d) 764 (N. D. Miss. 1931) ; see Woodford v. Glass, 168 Iowa 299, 302, 150 N. W. 69, 70 (1914); Bramhall v. Ferris, 14 N. Y. 41, 44 (1856); Seay v. Cockrell, 102 Tex. 280, 287, 115 S. W. 1160, 1163 (1909); cf. Butterfield v. Reed, 160 Mass. 361, 35 N. E. 1128 (1894); Millard v. Beaumont, 194 Mo. App. 69, 185 S. W. 547 (1916).

235. Abbot v. Perkins, 90 Kan. 45, 132 Pac. 1177 (1913); Albin v. Parmale, 70 Neb. 740, 98 N. W. 29 (1904); Nebraska Nat. Bank v. Bayer, 123 Neb. 391, 243 N. W. 115 (1932). In Albin v. Parmele, supra there was, in fact, a gift over upon alienation, and also a positive declaration of the conveyor's intent to give a life estate without the power of alienation. At the suit of thd conveyee, his deed transferring the property was set aside. Cf. McClure v. Cook, 39 W. Va. 579, 20 S. E. 612 (1894) (apparently holding a disabling restraint valid for the purpose of protecting a charge. See note 140, silpra); Trammell v. Johnston, $54 \mathrm{Ga} .340$ (1875) (disabling restraint upon legal life estate held valid, probably because life estate was regarded as held upon trust).

In some Kentucky cases, restraints in the disabling form, imposed upon legal life estates have been declared valid: Call v. Shewmaker, 24 Ky. L. Rep. 686, 69 S. W. 749 (1902) (life tenant allowed cancellation of deed which he had executed); Morton's Guardian v. Morton, $120 \mathrm{Ky} .251,85 \mathrm{~S}$. W. 1188 (1905) (disabling restraint barred sale for reinvestment under a statute authorizing sale only when not forbidden by the terms of the instru- 
A forfeiture restraint upon a legal life estate is not as objectionable. While a forfeiture may in some instances disappoint the expectations of creditors unaware of the restraint, usually the risk of loss of the property will suffice to induce the life tenant to pay his debts if possible. A forfeiture restraint does not give rise to the unpleasant spectacle of a debtor enjoying all the benefits of property and at the same time denying payment of his just debts.

Forfeiture provisions in respect to life estates usually take the form of a limitation to the remainderman upon breach of the condition. Less frequently, there is a limitation over to a third person. By the weight of authority these provisions are valid. ${ }^{236}$ If the life estate is subject

ment creating the estates to be sold); Lawson v. Lightfoot, $27 \mathrm{Ky}$. L. Rep. 217, \&4 S. W. 739 (1905) (life tenant and remaindermen were unable to make title to a purchasar because of a disabling restraint upon the life estate). Later Kentucky decisions, homerer, deny the validity of a disabling restraint upon a fee. See notes 55-57 supra. And in Brock v. Brock, $168 \mathrm{Ky} .847,183 \mathrm{~S}$. W. 213 (1916), it was held that a disabling retraint against involuntary alienation was void when imposed upon a life estate.

In an early Dlinois case, it was held that a legal life estate was subject to a valid disabling restraint, although there was absolutely nothing in the conveyance to suggeat an intent to impose such a restraint. Pulliam v. Christy, 19 Ill. 331 (1857). The casa had first come before the court two years earlier, as Christy v. Pulliam, $17 \mathrm{Ml}$. 58 (1855). In the report of that decision, there is no intimation that the life estate was inalienable. In Springer v. Savage, 143 Ill. 301, 32 N. E. 520 (1892), the court would seem again to have sustained a disabling restraint upon a legal life estate, but the decision is so bady reported that its actual effect is uncertain. These Illinois cases must now be regarded as completely overruled by Gray v. Shinn, 293 III. 573, 127 N. E. 755 (1920); and Randolph v. Wilkinson, 294 IIl. 508, 128 N. E. 525 (1920). See also comment on Illinois cass, infra note 236 .

236. Blackman v. Fysh, [1892] 3 Ch. 209; Conger v. Lowe, 124 Ind. 363, 24 N. E. 889 (1890); Lariverre v. Rains, 112 Mich. 276, 70 N. W. 583 (1897); Barnes v. Gunter, 111 ITinn. 383, 127 N. W. 398 (1910); Jones v. Bellinger, 91 S. C. 1, 73 S. E. 1049 (1912); Lynch v. Lynch, 161 S. C. 170,159 S. E. 26 (1931); Camp v. Cleary, 76 Va. 140 (18s2); Mears v. Taylor, 142 Va. 824, 128 S. E. 264 (1925); see City of Louisville v. Cooke, 135 Ky. 261, 263, 122 S. W. 144, 145 (1909).

The Ilinois decisions are quite irreconcilable. In an early decision, Waldo v. Cumminzs, 45 Ill. 421 (1867), it was held that a provision for forfeiture of a legal life etate upon alienation thereof was valid. The contrary, however, was held in Henderson v. Hamesi, 176 III. 302,52 N. E. 68 (1898); Streit v. Fay, 230 ml. 319, 82 N. E. 643 (1907). And later decisions declared broadly that no restraint could be imposed upon the alienation of either a fee or a life estate. Gray v. Shinn, 293 IIl. 573, 127 N. E. 755 (1920); Department of Public Works v. Porter, 327 III. 28, 158 N. E. 366 (1927). In the recent decision in Brumsey v. Brumsey, 351 Tll. 414,184 N. E. 627 (1933), however, a limitation over of a life estate upon alienation thereof was held valid.

In Iowa it would seem that a forfeiture restraint upon a legal life estate is void. Sae McCleary v. Ellis, 54 Iowa 311, 6 N. W. 571 (1880); MicCormick Harvesting Mfachine Co. v. Gates, 75 Iowa 343, 39 N. W. 657 (1888); Woodford v. Glass, 168 Iors 299, 150 N. W. 69 (1914); Glenn v. Gross, 185 Iow3 546, 170 N. W. 783 (1919).

Where a conveyance creates a life estate in terms, with a limitation over upon alienation thereof, and the remainder is limited to the heirs of the life tenant, the Rule in Shelley's Case, if in force, creates a fee in the parson designated as life tenant. The 
to an executory limitation over to the remainderman, it will vest in him upon breach of the condition, and will merge in his fee simple interest. In some instances, the language of the limitations may justify the inference of a determinable life estate, with a vested remainder following, which will come into possession whenever and however that life estate may terminate; in such situations, it is not necessary that there should be in express words a limitation to the remainderman upon alienation. ${ }^{237}$ In other instances, the limitations may be construed to create a determinable life estate, with a contingent remainder which can vest only in event of termination of the life estate by the death of the life tenant; in such a case, the conveyor has retained a defeasible reversion. ${ }^{238}$

If a remainder may be limited after a life estate determinable upon alienation, and if a life estate may be given over by an executory limitation conditioned upon alienation, the conveyor should be able to reserve to himself a power to terminate the life estate upon alienation, by a

forfeiture, then, being imposed upon a fee, is usually void. Diamond v. Rotan, 58 Tex. Civ. App. 263, 124 S. W. 196 (1910) ; Breinig v. Smith, 267 Pa. 207, 110 Atl. 285 (1920); cf. Hudson v. Hudson, 287 Ill. 286, 122 N. E. 497 (1919); Bradley v. Peixoto, 3 Vcs. 324 (Ch. 1797). If the limitation over upon alienation is to the heirs of the lifa tenant, it may be possible to infer that the word "heirs" was not used in such a sense as to require application of the Rule. Conger v. Lowe, 124 Ind. 368, 24 N. E. 889 (1890).

In jurisdictions where a disabling restraint upon an equitable life interest is void in the absence of special statutory provision, a forfeiture restraint is usually valid. Metcalfe $v$. Metcalfe, 43 Ch. D. 633 (1889); Bottom v. Fultz, $124 \mathrm{Ky}, 302,98$ S. W. 103 7 (1907); Bramhall v. Ferris, 14 N. Y. 41 (1856).

If there is a restraint upon alienation of both the life estate and the remainder, there is no reason why it may not be upheld as to the life estate, though void as to the remainder. Morton's Guardian v. Morton, $120 \mathrm{Ky}$. 251, 85 S. W. 1188 (1905); see Robsion v. Gray, 29 Ky. L. Rep. 1296, 97 S. W. 347 (1906). But contra, Henning v. Harrison, $76 \mathrm{Ky} .723$ (1878).

237. Lariverre v. Rains, 112 Mich. 276, 70 N. W. 583 (1897). Compare the form of the limitations in Streit v. Fay, 230 Ill. 319, 82 N. E. 648 (1907); Conger v. Lowe, 124 Ind. 368, 24 N. E. 889 (1890); City of Louisville v. Cooke, 135 Ky. 261, 122 S. W. 144 (1909); Diamond v. Rotan, 58 Tex. Civ. App. 263, 124 S. W. 196 (1910); Mears v. Taylor, 142 Va. 824, 128 S. E. 264 (1925). Since there is usually an express limitation to the remaindermen upon alienation of the life estate, it is usually not necessary to determine whether the future interest is technically a remainder or an executory limitation. Where the future interest is limited to a class, however, ascertainment of the class may depend upon the technical nature of the future interest. Blackman v. Fysh, [1392] $3 \mathrm{Ch}$. 209 ; cf. Jones v. Bellinger, 91 S. C. 1, 73 S. E. 1049 (1912).

238. In Scruggs v. Murray, 70 Tenn. 44 (1878), land was devised to W "during her natural life and she lives on it, and does not rent or sell it." "After her death", it was devised to $S$. W removed from the land and rented it. $S$ brought suit in equity to recover the land, with rental for its use, and damages for delapidations. The suit was dismissed on demurrer, on the ground that there was no limitation over upon alienation, but only a disabling restraint. It would seem that the devise might have been construed to create a determinable life estate with vested remainder. Cf. Lariverre v. Raing, 112 Mich. 276, 70 N. W. 583 (1897). 
reentry. While there is but little direct authority, this seems to be the general view. ${ }^{239}$

The arguments which will justify a forfeiture restraint upon a life estate are equally cogent with respect to such a restriction upon a term of years. In short term leases, especially, the lessor's control over occupancy of the premises is important. Forfeiture restraints upon terms of years have been held valid without respect to the length of the terms. $^{240}$ This doctrine is somewhat objectionable, in that it may enable a conveyor to evade the spirit of the rule against restraints upon the alienation of a fee, by the creation of a long term subject to a restraint. If a term of years is sufficiently long, it is substantially a fee.

The question may arise whether the owner of a term, alienation of which has not been restricted, can upon an assignment thereof impose a restraint upon transfer by his assignee. Since the assignor of the term has no interest in it after assignment, there is no convincing reason why he should be permitted to impose such a restraint. ${ }^{242}$

A restraint upon a term of years is rarely phrased in the disabling form. The restriction commonly takes the form of a covenant not to assign or sublet, with a provision for forfeiture in event of its breach. There is, therefore, little authority upon the validity of a disabling restraint imposed upon a term of years. ${ }^{243}$ Covenants against alienation

239. Lewis v. Lewis, 74 Conn. 630, 51 Atl. 854 (1902), considered on the merits in 76 Conn. 586, 57 Atl. 735 (1904); Jackson v. Groat, 7 Cow. 285 (N. Y. 1827); Gaines v. Sullivan, 117 S. C. 475, 109 S. E. 276 (1921); see Depayster v. Michael, 6 N. Y. 457, 491 (1852) ; Kerns v. Carr, 82 W. Va. 78, 81, 95 S. E. 605, 607 (1918). Contro: Department of Public Works v. Porter, 327 IIl. 28, 158 N. E. 366 (1927); see Blacketone Banl: v. Davis, 38 Mass. 42,43 (1838).

240. Roe d. Hunter v. Galliers, 2 T. R. 133 (K. B. 1787); Walker v. Wadley, 124 Gz. 275,52 S. E. 904 (1905); Gunning v. Sorg, 214 Ill. 616, 73 N. E. 870 (1905); Farr v. Kenyon, 20 R. I. 376, 39 Atl. 241 (1898); see GrAx, op. cit. supra note 205, f 101; 1 TIrFary, op. cit. supra note 186, at 921.

In several states there are statutory provisions restricting the acsignment of terms. See 1 TrFans, op. cit. supra, at 947 et seq.

241. In Gunning v. Sorg, 214 III. 616, 73 N. E. 870 (1905), a forfeiture restraint upon a term of ninety-nine years was held valid. See $G_{R A Y}$, op. cit. stopra note 205, \& 103.

If a term of years is conveyed subject to a restraint upon alienation, and the conveyee is also given the remainder, the restraint is upon the fee, and should be dealt with as such. See comment on Minter v. People's Nat. Bank, supro note 73.

242. GraY, op. cit. supra note $205 \S 102$. Gray thought the contrary had baen heid in Doe d. Norfolk v. Hawke, 2 East 481 (K. B. 1802). But see Sweet, supro note 157 at 238 n. 3.

243. Any provision in a lease, restricting alienation, should be construed to crente cither a condition or a covenant. Since such a provision is usually incerted for the protection of the lessor, it ought to be so construed as to give him a remedy for its breach. A mere disabling restraint cannot benefit him. See the discussion of restraints on alienation to members of a particular social group, supro, subtitle II, C., at footnote 174. Cf. Gasr, op. cit. supra note 205 , at $89 \mathrm{n}$; see note 42 , supra.

In Hobbs v. Smith, 15 Ohio 419 (1864), a ninety-nine year term was devisad with a 
of the term, however, have often been enforced in equity by injunction against transfer, even though forfeiture for breach of the covenant has been provided. ${ }^{24}$ In some instances, an assignee who has taken an assignment in violation of the provisions of the lease has been restrained from occupying the premises. ${ }^{245}$ The remedy of injunction against breach of a covenant not to alienate gives such a covenant, in considerable degree, the characteristics of a disabling restraint, as heretofore indicated. ${ }^{246}$ If this relief is obtainable where a covenant has been expressly made a condition subsequent, it must be assumed that it is equally available where the restraint is phrased in the disabling form.

IV

\section{Restraints Uton the Alienation of Future Interrests}

Restraints upon the alienation of future interests call for special consideration. When imposed upon a future interest, a restraint may in terms continue operative only so long as the future interest remains non-possessory; or, the restraint may be limited to continue for some possible period of time after the future interest has come into actual possession. The latter situation will be discussed first.

This type of restraint is illustrated in the well known case of Mandlebaum v. McDonell, ${ }^{247}$ in which land was devised to W. for life, and in remainder to several named persons, with a provision that the land should not be sold in the lifetime of $W$, nor until a certain remainclerman should have attained the age of twenty-five years. Clearly, the restraint was one which might continue operative after the remainder had come into possession. The court held the restraint void, treating it in the same way as a restraint upon a fee in possession. Once a remainder has come into possession, any restraint upon alienation of the possessory interest is as offensive to public policy as if the interest had been possessory when the restraint was originally imposed. While there is little specific discussion of the point, the decisions hold void a

disabling restraint against involuntary alienation. It was held that the restraint did not bar a sale of the term to satisfy a debt of the devisee.

244. Best v. Parsons, 207 Ala. 115, 92 So. 267 (1922); Boskowitz v. Cohn, 197 App. Div. 776, 189 N. Y. Supp. 419 (1st Dept, 1921); Proctor Troy Properties Co. v. Dugan Store, 191 App. Div. 685, 181 N. Y. Supp. 786 (3d Dept. 1920). Injunctive reliof was also allowed in the following cases, in which it did not clearly appear that the leaso contained a forfeiture provision: McEacharn v. Colton, [1902] A. C. 104; Godfrey v. Blacli, 39 Kan. 193, 17 Pac. 849 (1888); see Knoepker v. Redel, 116 Mo. App. 62, 92 S. W. 171 (1906). But cf. Spear v. Fuller, 8 N. H. 174 (1835).

245. Best v. Parsons; Godfrey v. Black; Proctor Troy Properties Co. v. Dugan Storo; Boskowitz v. Cohn, all supra note 244.

246. See discussion of restraints on alienation to members of a particular social group, supra, subtitle II, C.

247. 29 Mich. 78 (1874). 
restraint upon alienation of a future interest if the restraint may continue effective after the interest has become possessory, provided, that the restraint is one which would be void if imposed upon a fee in possession. The rule stated for this type of restraint is applicable whether the future interest is an absolutely vested remainder, ${ }^{213}$ an executory limitation in the nature of a springing or shifting use, ${ }^{210}$ a contingent remainder, ${ }^{250}$ or a vested remainder defeasible in some degree. ${ }^{251}$ No authority has been found which has divided the restraint, and upheld it for the period of time during which the future interest may remain non-possessory.

Where the restraint is limited in terms to the period during which the future interest is non-possessory, it could, with some plausibility, be held valid. According to the older common law, certain types of

248. Little v. Bowman, 276 Ill. 125, 114 N. E. 519 (1916); Reeder v. Antrim, 64 Ind. App. 83, 110 N. E. 568 (1915) ; Hause v. O'Leary, 136 Minn. 126, 161 N. W. 392 (1917); Turner v. Hallowell Savings Institution, 76 Me. 527 (1884); Loosing v. Loosing, 85 Neb. 66, 122 N. W. 707 (1909); Davis v. Davis, 39 ITicc. 90, 78 N. Y. Supp. 699 (Sup. Ct. 1902) ; Pardue v. Givens, 54 N. C. 306 (1854); Gray v. Farolins, 133 N. C. 1, 45 S. E. 363 (1903); Re Watson and Woods, 14 Ont. Rep. 48 (Ch. 1837); Heddletone v. Heddlestone, 15 Ont. Rep. 280 (1888); see Schermerhorn v. Negus, 1 Denio 448 (N. Y. 1845.) The rule is the same where the restraint is imposed on 3 freehold aiter a term of years: Williams v. Sealy, 201 N. C. 372, 160 S. E. 452 (1931); II'Cullough's Heirs v. Gilmore, $11 \mathrm{~Pa}$. 370 (1849); Cobb v. Moore, 90 W. V3. 63, 110 S. E. 468 (1922). In this situation, the fact that the future interest is not technically a remainder, but rathor a freehold in possession, furnishes a further argument for holding the restraint invalid.

Where a restraint upon the alienation of a life estate in possession would be valid, a restraint upon a remainder for life is likewise valid. Conger v. Lowe, 124 Ind. 363,24 N. E. 889 (1890) ; McClure v. Cook, 39 W. Va. 579, 20 S. E. 612 (1894).

Under the Kentucky doctrine permitting restraints on a fee when reaconably limited in time, a restraint upon a vested remainder may be valid. E.g., a restraint upon alienation of the remainder during the life of the life tenant; Lawson v. Lightfoot, 27 Ky. L. Rep. 217,84 S. W. 739 (1905) ; or during the life of the life tenant and a reasonable time thereafter; see Speckman v. Meyer, 187 Ky. 687, 689, 220 S. W. 529, 530 (1920). A parpatual restraint upon alienation of a remainder is void. Henning v. Harricon, $76 \mathrm{Ky} .723$ (1375); see Robsion v. Gray, 29 Ky. L. Rep. 1296, 97 S. W. 347 (1906). A disabling restraint upon a remainder is void. Brock v. Brock, $168 \mathrm{Ky} .847,183$ S. W. 213 (1916). Sce aleo supra notes 54-56, 101-105.

249. Hudson v. Hudson, 287 Ill. 286, 122 N. E. 497 (1919); MIcFadden v. MicFadden, 302 IIl. 504, 135 N. E. 31 (1922); Kaufman v. Burgert, 195 Pa. 274, 45 Atl. 725 (1900); White v. Dedmon, 57 S. W. 870 (Tex. Civ. App. 1900).

250. Department of Public Works v. Porter, 327 III. 28, 158 N. E. 366 (1927); Perry v. Brown, 45 R. I. 210, 121 Atl. 209 (1923); see Morton's Guardian v. Irorton, 120 Ky. 251, 261, 85 S. W. 1188, 1190 (1905) ; cf. Butterfield v. Reed, 160 MLacs. 361, 35 N. E. 1123 (1894); Goffe v. Karanyianopoulos, 166 Atl. 547 (R. I. 1933). In Wright v. Jenls, 124 Kan. 604, 261 Pac. 840 (1927), a restraint upon alienation of a contingent remaindar was held void for the specific reason that it was a mere disabling restraint.

251. In re Groth's Will, 128 Misc. 905, 220 N. Y. Supp. 505 (Surr. 1927); Latimer v. Waddell, 119 N. C. 370, 26 S. E. 122 (1896). In the case, Re Winstanley, 6 Ont. Rep. 315 (Ch. 1884), a qualified restraint upon a defeasible remainder was held valid under the liberal rule then favored by the Ontario courts. See text supro, at note 62 et seq. 
future interests were inalienable; the contingent remainder and the executory limitation growing out of the Statute of Uses were the principal pertinent examples. Since these interests were inalienable in the absence of a restraint, the restraint could not constitute an impediment to alienation. Its only effect was, in those cases where a forfeiture had been stipulated, to penalize the person who attempted to transfer the inalienable future interest, by depriving him of the chance that it might vest in him at a future time. It might be argued further that, even with respect to the alienable future interests, such as the reversion and the vested remainder, there was no clear policy in the law favoring alienability as against a positive restraint. It is well known that the alienation of a future interest apart from the possessory estate involves a sacrifice of value. Equity in early times developed a doctrine which gave relief against the transfer of such interests under certain circumstances. ${ }^{252}$

In England, a forfeiture restraint upon a contingent future interest for the period prior to vesting is valid. ${ }^{263}$ There are a few American decisions which tend in the same direction. ${ }^{254}$

It would seem by the English rule that a forfeiture restraint upon at vested remainder for the period during which it remains non-possessory

252. Where a future interest has been transferred for an inadequate consideration, such transfer will be set aside in equity. The burden is upon the purchaser to prove the fairness of the transaction. See 2 Ponreroy, EquTTY JURISPRUdence (4th ed, 1918) 8953.

253. Large's Case, 3 Leon. 182 (K. B. 1587) (contingent remainder in land); Churchill v. Marks, 1 Coll. 441 (Ch. 1844) (equitable contingent future interest in shares of stock); Barnett v. Blake, 2 Drew \& Sm. 117 (Ch. 1862) (equitable contingent future interest in land); see Graham v. Lee, 23 Beav. 388 (Rolls Ct. 1857); Samuel v. Samuel, 12 Ch. D. 152 (1879); Sweet, supra note 157 at 245.

It was held in In re Porter, [1892] $3 \mathrm{Ch} .481$, that a forfeiture restraint upon an equitable future interest, vested subject to divestiture, was valid. See comment on this case in Sweet, supra note 157 at $246 \mathrm{n}$.

254. In Gordon v. Tate, 314 Mo. 508, 284 S. W. 497 (1926), land had been devised on trust for the use of $G D$ for twenty-one years, with a direction that at the end of said period it should be transferred to $G D$ if living, otherwise to her children. It was stipulated that during the existence of the said trust period, title to the whole property should bo vested in the trustee, and that no interest of any devisee should be assignable or liable for debts; any devisee who should attempt to assign should forfeit his interest. The interest of $G D$ was sold under execution to the plaintiff, who brought an action to recover the land. Judgment was for the defendant, the court holding that the interest of GD was inalienable. This interest was said to be, in part, a "contingent remainder," and it was declared that alienability was not an essential attribute of such an interest. The restraint was apparently given the literal effect of a disabling restraint. It is not clear whether the court viewed the "contingent remainder" of which it spoke as a legal or an equitable interest. It would seem that the whole interest of $G D$ was equitable, and that it might be viewed as a present interest subject to defeasance. In Minter v. People's National Bank, 95 Ind. App. 204, 182 N. E. 87 (1932), the devisee had been given a term of years and also a contingent future interest. It was beld that a restraint imposed upon alienation by her voided her mortgage of the fee. See comment on this case, supro note 73. 
is also valid. ${ }^{255}$ Probably the rule in Pennsylvania is the same. ${ }^{230}$ The weight of American authority, however, is clearly contra. ${ }^{257}$

[To be continued]

255. There are several English decisions to this effect: Kearsley v. Woodcocl; 3 Hare 185 (Ch. 1843); Kiallmark v. Kiallmark, 26 L. J. (N. S.) 1 (Ch. 1856); In re Payns, 25 Beav. 556 (Ch. 1858); In re Goulder [1905] 2 Ch. 100. While these caess all involved equitable future interests, they are not less significant by reason of that fact, since in Englard equity has, in general, followed the legal rules in respect to restraints. See note 29, safro. There is one English decision contrary to those above cited: Powell v. Bogsis, 35 Beav. 535 (Ch. 1866). See comment on the rule adopted in the majority of the Englich cars in Sweet, supra note 157 , at 246 , to the effect that it is difficult to justify "on princip!e." Sas also, Grap, op. cit. supro note $205, \S \S 48-50$.

256. It is the established rule in Pennsylvania that alienation of a legacy may be restrained for the period during which it remains in the hands of the executor, though no technical trust has been created. No attempt by a creditor to reach the legacy in the hands of the executor can be successful. The legacy is thus protected "in trancit" from the executor to the legatee. Estate of Beck, 133 Pa. 51, 19 Atl. 302 (1890); Goe's Estate, $146 \mathrm{~Pa} .431,23$ Atl. 383 (1892). This doctrine upholds a disabling restraint upon an interest which is not strictly a future interest, and which would seem legal in some aspacts. Such a restraint has been held void in Massachusetts. Lathrop v. Merrill, 207 MInes. 6, 92 N. E. 1019 (1910). The Pennsylvania rule above mentioned, therefore, undoubtedly extends permissible restraints outside of the strictly equitable field. In Barker's Ectate, 159 Pa. 51S, 28 Atl. 365 (1894), the owner of a vested equitable future interest who had as signed it in violation of a disabling restraint was held entitled, nevertheless, to a transfer of the same from the trustee. It was declared broadly that the alienation of even a vested future interest might be restrained for the period prior to possession.

A forfeiture restraint upon the alienation of a legal vested remainder wos held valid in Glenn v. Gross, 185 Iowa 546, 170 N. W. 783 (1919). There, however, the conveyor brd reserved a life estate, and the power to mortgage in fee; he had also charged the land conveyed with payment of certain sums after his death. See notes 140, 235, supro.

257. Voellinger v. Kirchner, 314 III. 398, 145 N. E. 638 (1924); Hall v. Tufts, 35 3racs. 455 (1836); Läthrop v. Merrill, 207 Miass. 6, 92 N. E. 1019 (1910); Watkins v. IFinor, 214 Mich. 380, 183 N. W. 186 (1921); Toledo Loan Co. v. Larkin, 25 Ohio Cir. Ct. 209 (1903). In all these cases, the restraints were in the disabling form, but that fact dos not appear to have been controlling.

In Randolph v. Wilkinson, 294 IIl. 508, 128 N. E. 525 (1920), a restraint was held roid as to the life estate expressly devised, and also as to the reversionary interest which descended to the devisees. 